\title{
都市ヒートアイランド現象の空調・給湯用 エネルギー消費への影響評価
}

\author{
平野勇二郎 ${ }^{1} \cdot$ 茅 陽一 $^{2} \cdot{\text { 柴崎亮 }{ }^{3}}^{3}$ \\ '学生会員 修士 東京大学大学院 社会基盤工学専攻 博士課程 （テ 153-8505 東京都目黒区駒場 4-6-1） \\ ${ }^{2}$ 工博 慶應義熟大学教授 政策・メディア研究科（テ252-8520 神奈川県藤沢市遠藤 5322） \\ ’正会員 工博 東京大学教授 空間情報科学研究センター（テ153-8505 東京都目黒区駒場 4-6-1）
}

\begin{abstract}
本研究の目的は, 東京大都市圈を対象とし, ヒートアイランド現象により生じている冷房用エネルギー 消費の増大と暖房・給湯用エネルギー消費の減少をそれぞれ定量化し，ヒートアイランド現象のエネルギ 一消費への影響を明らかにすることである．そこでまず，気温を考慮したエネルギー消費原単位の推定式 を作成した。また，現状の気温分布と，ヒートアイランドが生じないと想定した場合の気温分布を推定し た．その上で，それぞれの気温分布について，エネルギー消費の空間分布をメッシュ単位で推定し，結果 を比較した。この結果, 東京においてはヒートアイランド現象により, 空調・給湯用エネルギーの年間総 消費量は家庭部門では減少，業務部門では増大しており，全体では減少していることが明らかになった。
\end{abstract}

Key Words : heat island, energy consumption, spatial distribution, urban thermal environment, climatic condition

1.はじめに

ヒートアイランド現象に代表される都市気温の高 温化（以下，すべて「ヒートアイランド現象」と呼 ぶ）は今後の都市の環境管理においてますます重要 な問題になると考えられる。ヒートアイランド現象 の解明は，土木・建築・地理・気象などのさまざま な分野において古くから研究テーマであり, 数多く の知見が得られている(1).2).31. 今日ではこうした現象 に関する知見は十分に蓄積され，今後はヒートアイ ランド現象によるインパクトを緩和するという段階 に移行すべきであると言われている4).そのため, 近年はヒートアイランド緩和策の提案やその効果の 検討などの報告も増えつつあり ${ }^{5) .6)}$, 現実的な政策へ の応用が期待されている。しかしながら，実際には ヒートアイランド現象により生じる社会・経済的な .インパクトが必ずしも明確ではないため,こうした 緩和策の効果を示すことが困難であると言える。

こうした背景から，ロサンゼルスでは定量的にヒ ートアイランド現象のエネルギー消費や大気污染, 気象などへの社会・経済的な影響評価が行われてい る4. しかしながら東京においては，ヒートアイラ ンド現象によりさまざまな社会・経済的なインパク トが生じるという定性的な指摘は多いが，定量的な 検証は十分になされているとは言えない.

とくに東京において最もよく指摘されるのは,
ヒートアイランド現象による冷房用エネルギー消費 の増大である ${ }^{2) .3 .7)}$. これを東京全体の冷房用エネル ギー消費量と平均気温の関係から概算した例はある が(2).8), 空間分布を考慮した評価は行われていない. したがって，これは複雑な空間分布を形成するヒー トアイランド現象の影響評価としては必ずしも十分 ではない.また, 通常はこうした熱環境の評価は最 も快適性を損なう夏季について検討されるが，エネ ルギー消費量に関する影響評価を行う場合には，暖 房・給湯用エネルギー消費の減少も考慮し, 年間を 通じた評価を行う必要がある。しかしながらこうし た検討もなされていない.

そこで本研究は東京大都市圏を対象とし（図1）, ヒートアイランド現象により生じている冷房 用エネルギー消費の増大および暖房・給湯用エネル ギー消費の減少をそれぞれ空間分布を考慮して定量 化し, ヒートアイランド現象が空調・給湯用エネル ギー消費に与えている影響を明らかにすることを目 的とした。

なお，実際にはこうしたヒートアイランド現象に よるエネルギー消費の増減は, その都市の気候条件 や土地利用形態などにより異なるものである。本研 究で提案する手法は一般性があると考えているが, 評価結果についてはあくまで東京における結果であ ることを最初に述べておく. 

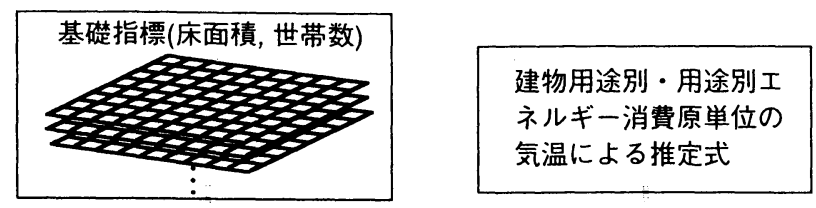

ヒートアイランドの

有無による気温分布

の変化
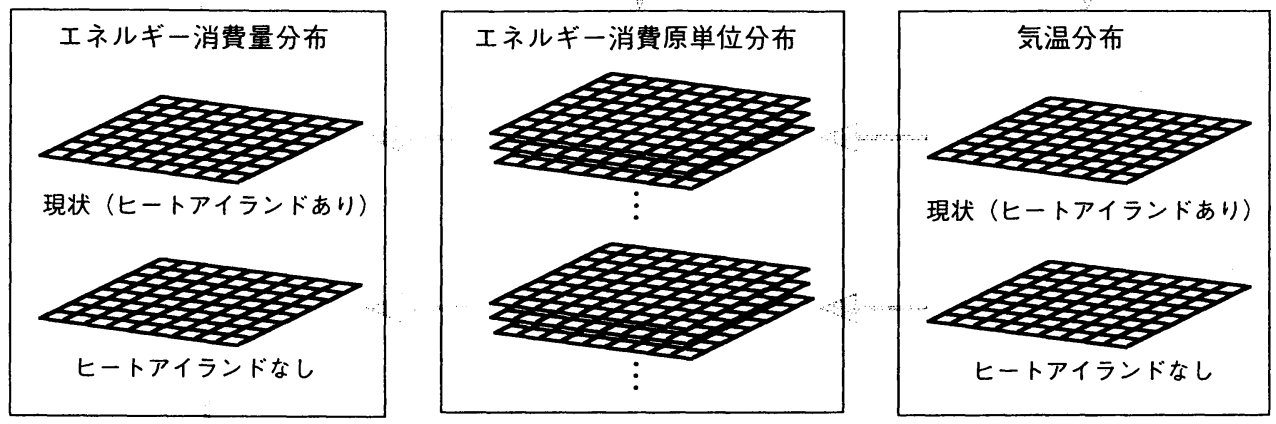

ヒートアイランド現象がエネ

ルギー消費量に与える影響

図-2 本研究の全体構成

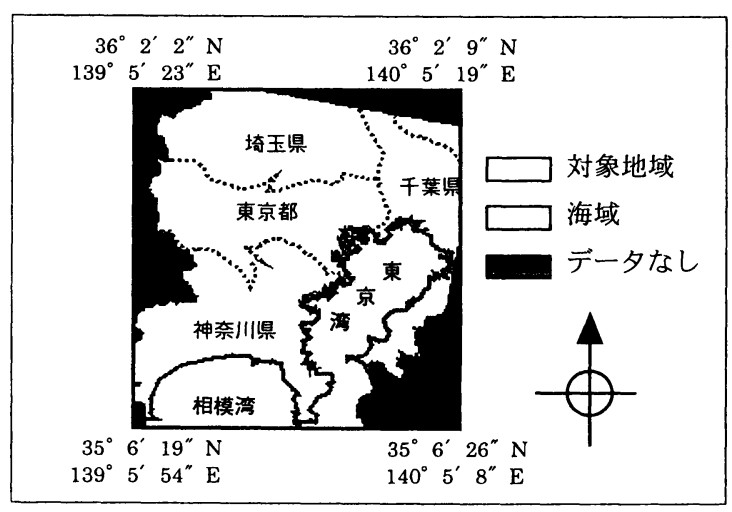

図-1 本研究における対象地域

\section{2. 方法}

気温の変化に対するエネルギー消費の変動の大き さ（「気温感応度」と呼ぶ）を調査した例は多く ${ }^{91.10)}$, これにより暑夏や冷夏などのマクロな気温変化や 日々の気象条件がエネルギー消費に与える影響の評 価が行われている．しかしながら従来の気温感応度 の算出はエネルギー供給側の実績データを用いて行 なわれることが多く，対象地域内の詳細な空間分布 を把握することは困難である。したがってこれは， ヒートアイランド現象のような複雑な空間分布を形 成する現象の影響評価には適用できない。

一方，エネルギー消費の空間分布に関しても多く の研究がなされている ${ }^{11), 121}$ 。これらの研究は, 工ネ
ルギー消費原単位を基礎指標の空間分布のデータに 乗じるという方法により行われている. エネルギー 消費原単位とは床面積や世帯あたりのエネルギー消 費量であり，基礎指標とはその分母となる床面積や 世帯数である。ただし，エネルギー消費原単位は気 温による影響を考慮していないので,この方法をそ のままヒートアイランド現象の影響評価に用いるこ とはできない.

そこで本研究では図-2に示す方法により，エネル ギー消費の気温感応度と空間分布の両方を考慮した 影響評価を行った，以下にその手順を説明する。

まずエネルギー消費原単位を気温の関数として表 現することにより，エネルギー消費原単位の気温に よる推定式を作成した。その一方で, 現状の気温分 布と都市の影響がない場合の仮想的な気温分布を メッシュ単位で推定した：その上でこれらの気温の 各メッシュに最初に作成した推定式を適用し，それ ぞれの気温分布に応じたエネルギー消費原単位を メッシュ単位で推定した。次にこのエネルギー消費 原単位の各メッシュを基礎指標のメッシュデータに 乗じることにより，現状の気温分布とヒートアイラ ンドがない場合の気温分布のそれぞれに応じたエネ ルギー消費量を推計した。そしてこれらを比較し, ヒートアイランド現象がエネルギー消費に与える影 響を定量化した。

なお本研究の方法では，よく指摘されるエネルギ 一消費とヒートアイランド現象のフィードバックル ープの効果は考慮されていない。実際には，ヒート 
表-1 エネルギー消費原単位データの出典

\begin{tabular}{|c|c|c|}
\hline 資料1 & $\begin{array}{c}\text { 家庭部門 } \\
\text { (年合計值) }\end{array}$ & $\begin{array}{l}\text { 澤地 ほか (1994)：日本建築学 } \\
\text { 会 計画系論文集, No.462, pp.41- } \\
48 .\end{array}$ \\
\hline 資料2 & $\begin{array}{l}\text { 家庭部門 } \\
\text { (月別・時刻 } \\
\text { 別パターン) }\end{array}$ & $\begin{array}{l}\text { 財団法人 空気調和・衛生工学会 } \\
\text { (1994): 『都市ガスによるゴ } \\
\text { ジェネレーションシステム計画 } \\
\text { 設計と評価』,pp.138-142. }\end{array}$ \\
\hline 資料3 & $\begin{array}{l}\text { 業務部門 } \\
\text { (年合計值, } \\
\text { 月別・時刻 } \\
\text { 別パターン) }\end{array}$ & $\begin{array}{l}\text { 日本地域冷暖房協会 (1995): } \\
\text { 『プロジェクト2010 日本全国地 } \\
\text { 域冷暖房導入可能性調査研究平成 } \\
\text { 6年度報告書』,pp.22-27. }\end{array}$ \\
\hline
\end{tabular}

アイランド現象の形成要因は人工排熱以外にも数多 く, また東京の人工熱排出源 ${ }^{13}$ のうち, 産業部門 · 運輸部門や民生部門の動力・照明用エネルギー消費 の占める割合も大きい. したがって空調・給湯用工 ネルギー消費はヒートアイランド現象の形成要因の ごく一部であり, しかも後述する本研究の計算結果 から，ヒートアイランド現象による空調・給湯用工 ネルギー消費の変動はさらにその数％程度である。 したがってこれが気温に影響し，それが再び空調・ 給湯用エネルギー消費に与える影響は無視して差し 支えないと考えられる.

\section{3. エネルギー消費原単位の推定式作成}

\section{(1) 利用データ}

本研究で用いたエネルギー消費原単位の出典を表$1 に$ にこれらのデータの分類および基礎指標を表-2 にそれぞれ示す。なお，本研究において用いたデー 夕はいずれも1次換算值である。

家庭部門のエネルギー消費原単位に関する調査は 比較的多いと言える ${ }^{13)}$. ただし, 戸建住宅と集合住 宅では原単位は大きく異なること胡, 都心と郊外で は戸建・集合の比率が異なることを考慮すれば，本 研究のような目的では，これらを区別して集計した デー夕を用いる必要がある。そこで本研究では家庭 部門の原単位の年間合計值として資料1の東京のデ ータを用いた。この資料では, 集合住宅は複数のデ 一タが記載されているため, サンプル数により加重 平均した。 ただし，本文中にはずれ值であることが 明記されているサンプルは除外した。また，このデ 一夕から月別值・時別值を得るため, 資料 2 に記載 された住宅の月別・時刻別需要パターンのデータを 用いた。

業務部門のエネルギー消費原単位は，年間総消費 量, 月別・時刻別パターンとも資料3のデータを用
表-2 エネルギー消費原単位データの分類

\begin{tabular}{|c|c|c|c|}
\hline 部門 & 建物用途 & 基礎指標 & 用途 \\
\hline 家庭部門 & $\begin{array}{l}\text { 戸建住宅 } \\
\text { 集合住宅 }\end{array}$ & 世帯数 & \\
\hline 業務部門 & $\begin{array}{l}\text { 病院 } \\
\text { 事務所 } \\
\text { 商業施設 } \\
\text { ホテル } \\
\text { 娛楽施設 } \\
\text { 文化施設 } \\
\text { 学校 }\end{array}$ & 床面積 & $\begin{array}{l}\text { 暖房用 } \\
\text { 冷房用 } \\
\text { 給湯用 }\end{array}$ \\
\hline
\end{tabular}

いた，業務部門は，家庭部門と比較して建物の種類 が多くエネルギー使用状況も多様であるため, 調査 例が少ない ${ }^{13)}$. このため本研究では, 体系的である 上, 床面積のデータとの建物用途の分類が明確なデ 一夕として, 資料3のデータが適切であると判断し た。なお，資料3には「冷熱消費」という用語が用 いられているが, 出典である早稲田大学・尾島研究 室資料から，これは除去熱量ではなく冷房用エネル ギー消費の意味であると考えられる。

これらの時刻別パターンのデータは冬季, 夏季, 中間季の区分となっているものが多い。そこで冬 季, 夏季, 中間季の代表月をそれぞれ1月，8月，4 月とし，他の月はこれらをもとに気温により比例配 分する形で補間した。その上で年間総消費量を月 別・時刻別パターンにより配分し，建物用途別・用 途別・月別・時刻別エネルギー消費原単位を計算し た。

\section{(2) 推定式の作成と精度評価}

前述した建物用途別 · 用途別 · 月別 - 時刻別工六 ルギー消費原単位を月別平均気温と対応させること により，気温からエネルギー消費原単位を推定する ための建物用途別・用途別・時刻別の推定式を作成 した．原単位データの大半が過去 10 年程度の期間に 都心部で調査されたものであることから, 気温デー 夕は東京23区内の大気污染常時監視測定局20地点に おける 1984 1993年の月別・時刻別平均值を用い た。

以下に事務所における14時の冷房用エネルギー消 費原単位を例とし，この作成方法を説明する。ま ず, エネルギー消費原単位のデータと平均気温のデ 一タを表-3に, これらの散布図を図-3に示す.

図-3から，4月頃の気温を境界として傾きが変化 していることが読みとれる．空調が稼働している限 り，関係は直線的であると考えられるが，通常はあ 
表-3 事務所における14時の冷房用エネルギー消費原単位 $\left(\mathrm{Kcal} / \mathrm{m}^{2}\right.$. 時) と 14 時の月別の平均気温 $\left({ }^{\circ} \mathrm{C}\right)$

\begin{tabular}{|c|c|c|c|c|c|c|c|c|c|c|c|c|}
\hline & 1月 & 2月 & 3月 & 4月 & 5月 & 6月 & 7月 & 8月 & 9月 & 10月 & 11月 & 12月 \\
\hline 原単位 & 1.54 & 1.70 & 1.85 & 3.82 & 16.31 & 34.69 & 46.19 & 49.89 & 41.69 & 18.78 & 4.14 & 2.15 \\
\hline 平均気温 & 8.7 & 9.1 & 11.7 & 17.6 & 21.4 & 24.2 & 27.5 & 29.7 & 25.8 & 20.1 & 15.8 & 11.4 \\
\hline
\end{tabular}

表-4 エネルギー消費原単位の推定式作成方法（事務所における冷房用，14時の例）

\begin{tabular}{|c|c|c|c|c|c|}
\hline & 回帰式を作成する月の組み合わせ & 回帰式 I & 回帰式 II & $\begin{array}{c}\text { 交点 } \\
\left({ }^{\circ} \mathrm{C}\right)\end{array}$ & $\begin{array}{c}\text { 平均二 } \\
\text { 乗誤差 }\end{array}$ \\
\hline $\mathrm{A}$ & $\mathrm{I}: 1,2$ 月, II $: 12,3,11,4,10,5,6,9,7,8$ 月 & $E=-1.82+0.39 T$ & $E=-37.65+2.90 T$ & 14.22 & 4.26 \\
\hline $\mathrm{B}$ & $\mathrm{I}: 1,2,12$ 月, II $: 3,11,4,10,5,6,9,7,8$ 月 & $E=-0.32+0.22 T$ & $E=-43.60+3.15 T$ & 14.77 & 3.55 \\
\hline $\mathrm{C}$ & $\mathrm{I}: 1,2,12,3$ 月, II $: 11,4,10,5,6,9,7,8$ 月 & $E=0.35+0.14 T$ & $E=-58.00+3.73 T$ & 16.26 & 2.52 \\
\hline $\mathrm{D}$ & $\mathrm{I}: 1,2,12,3,11$ 月, II $: 4,10,5,6,9,7,8$ 月 & $E=-1.79+0.36 T$ & $E=-63.97+3.96 T$ & 17.25 & 2.36 \\
\hline $\mathrm{E}$ & $\mathrm{I}: 1,2,12,3,11,4$ 月, II $: 10,5,6,9,7,8$ 月 & $E=-1.21+0.30 T$ & $E=-58.85+3.77 T$ & 16.63 & 2.46 \\
\hline $\mathrm{F}$ & $\mathrm{I}: 1,2,12,3,11,4,10$ 月, II $: 5,6,9,7,8$ 月 & $E=-10.04+1.10 T$ & $E=-65.37+4.01 T$ & 19.05 & 3.09 \\
\hline $\mathrm{G}$ & $\mathrm{I}: 1,2,12,3,11,4,10,5$ 月, II $: 6,9,7,8$ 月 & $E=-11.31+1.22 T$ & $E=-29.48+2.71 T$ & 12.18 & 6.37 \\
\hline $\mathrm{H}$ & $\mathrm{I}: 1,2,12,3,11,4,10,5,6$ 月, II $: 9,7,8$ 月 & $E=-18.25+1.78 T$ & $E=-11.78+2.08 T$ & -21.26 & 15.34 \\
\hline $\mathrm{I}$ & $\mathrm{I}: 1,2,12,3,11,4,10,5,6,9$ 月, II $: 7,8$ 月 & $E=-22.99+2.15 T$ & $E=-0.25+1.69 T$ & 49.11 & 9.73 \\
\hline
\end{tabular}

$E:$ エネルギー消費原単位 $T:$ 気温

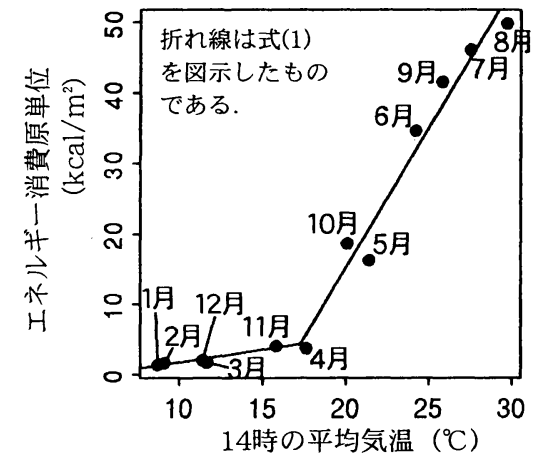

図-3 平均気温とエネルギー消費原単位の散布図 (事務所における冷房用, 14時の例)

る気温を境界として空調機器が稼働しはじめるた め，結果としてこのような分布になっていると考え られる。このためこうした傾向は，8月の学校を除 く他のすべての建物用途・時刻において見られた。 また傾きは逆であるが，暖房用に関しても同様で あった。

このような傾きの変化は図中に示したような折れ

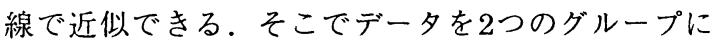
分け，それぞれの回帰式を作成した。グループ分け は複数の組み合わせが考えられるが，その中で平均
二乗誤差が最小となる組み合せを選択した。以下に その例を示す.

まず表-3のデー夕を気温により昇順に整列化し た.この例では $1,2,12,3,11,4,10,5,6$, $9 ， 7 ， 8$ 月の順番である. したがって，表-4に示す ような 9 通りの組み合わせが可能であることがわか る.そこで表-4に示した通り，これらのすべての組 み合わせについて $2 つ の$ 回帰式を作成し，さらにそ の回帰直線の交点となる気温を計算した。 その上 で，交点の気温を境界として，それぞれの回帰式に より気温からエネルギー消費原単位を推定した場合 の平均二乗䛊差を算出した.

表-4から，組み合わせDにおいて平均二乗誤差が 最小になっていることがわかる.したがって，14時 の事務所における冷房用エネルギー消費原単位の推 定式は,

$$
\begin{gathered}
T \leqq 17.25 \text { の場合 } \\
E=-1.79+0.36 T \\
T>17.25 \text { の場合 } \\
E=-63.97+3.96 T
\end{gathered}
$$

$T$ : 平均気温 $\left({ }^{\circ} \mathrm{C}\right)$

$E$ : 冷房用エネルギー消費原単位 (Kcal $/ \mathrm{m}^{2}$. 時)

となる。 
同様の方法を用い，暖房用・冷房用のそれぞれに ついて, エネルギー消費原単位の気温による推定式 を建物用途別・時刻別に作成した。ただし, 学校は 8月のデータがはずれ值であったため，これを除外 して推定式を作成した。給湯用に関しては気温との 関係が直線的であるため, 通常の単回帰式を作成 し，これを推定式とした。また，全ての推定式つい て月別に残差を計算した。なお，ここでは建物用途 別·用途別 · 時刻別の $648(9 \times 3 \times 24)$ の推定式が 得られたが，数が多いので揭載は省略する.

次に，これらの推定式の信頼性について検討し た. 本研究では気温の変化に対するエネルギー消費 原単位の変化を推定するために用いることから，推 定式の傾きの信頼性や折れ線で近似することの妥当 性などがとりわけ重要であると言える。このため, この評価には相関係数を用いることが適切であると 判断した。 そこでそれぞれの推定式について, 実際 のエネルギー消費原単位と気温による推定值の相関 係数を計算した。この結果，暖房用に関しては全て $R=0.97$ を超えた。冷房用は，学校が $R=0.96 \sim 0.97$ 程度であったが，他の建物用途は全て $R=0.97$ 超え た。また給湯用はほとんどが $R=0.8$ を超えた。給湯 用が $R=0.8$ 以下であったのは， 2 時と 3 時の住宅およ び9時の商業施設だけある。給湯用エネルギー消費 には気温感応があるが, 住宅における深夜の入浴の 頻度や店舗の開店時のエネルギー消費の立ち上がり も季節依存しており, 結果としてこれらの相関係数 が下がった可能性が高い。ただしこれらはいずれも 絶対値が非常に小さいため, 解析には影響しないと 考えられる。この検討結果から，本章で作成した推 定式は十分に利用可能な精度であると判断した。

\section{4. 月別・時刻別気温分布のメッシュ推定}

\section{(1) 重回帰式による気温分布推定}

気温分布の推定方法の模式図を図-4に示す。本研 究と同様の対象地域において, 月別・時刻別平均気 温を平均二乗誤差 $0.3 \sim 0.6{ }^{\circ} \mathrm{C}$ 程度の精度でメッシュ に展開する手法がすでに示されている ${ }^{14)}$.これは， まず気温観測点の周辺の地域条件からその地点の平 均気温を説明する重回帰式を作成し，次にそれを説 明変数のメッシュデータに当てはめることにより各 メッシュの気温を推定するという手法である。地域 条件として周辺の土地利用や地形因子, 海岸からの 距離などを用いている. 被説明変数の気温デー夕は 対象地域内96地点の大気污染常時監視測定局による 1984 1993年の月別・時刻別平均値であり，これ は前章で用いた気温データと対応するものである。
各気象観測点の月別・時刻別平均気温を土地被

覆条件などから説明する重回帰式 ${ }^{(4)}$

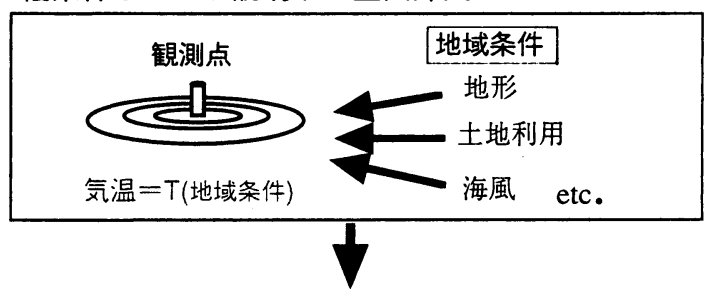

各メッシュへ当てはめ, 気温分布を推定

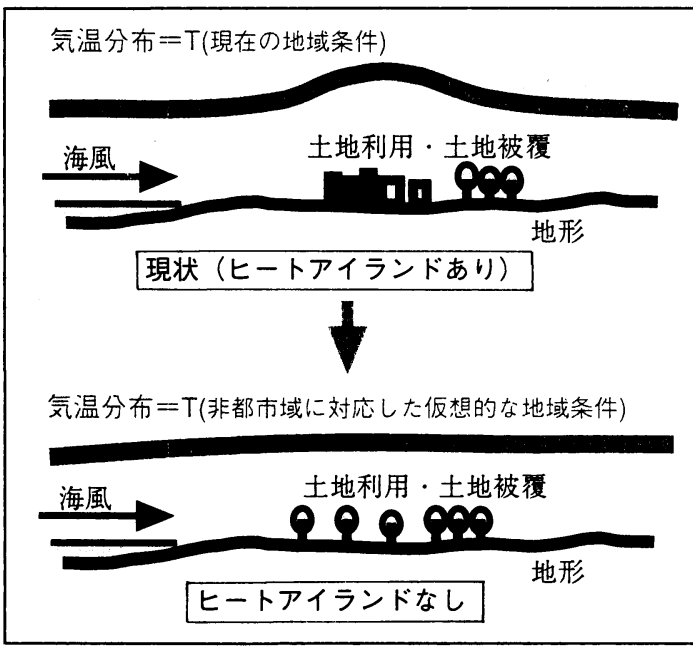

図-4 気温分布推定の模式図

そこで本研究ではまず，この手法を用いて対象地 域の現状の月別・時刻別平均気温分布を $1 \mathrm{~km}$ メ シュで推定した．ただし，ここでは説明変数として 緑被率のかわりにリモートセンシングデータ（1993 年10月28日のLandsat TM）の植生指標（NDVI） を用いた。これにより説明変数の多重共線性は増大 したが, 平均二乗䛊差は減少した。このため,ここ では説明変数の評価ではなく気温の推定が目的であ ることを考慮し，植生指標を用いる方が適切である と判断した。ここで得られた月別・時刻別気温推定 式の例として，7月 15 時および 12 月 21 時の式を次に 示す.

$$
\begin{aligned}
T_{715}= & 2472.0-0.0229 x_{a}+2.646 x_{b}-1.055 x_{c}+38.11 x_{d} \\
& +15.36 x_{e}+29.85 x_{f}+8.388 x_{g}+11.52 x_{h}-188.2 x_{i} \\
T_{1221}= & 842.6+0.3187 x_{a}+12.45 x_{b}-4.029 x_{c}-18.01 x_{d} \\
& -29.33 x_{e}+7.955 x_{f}+76.56 x_{g}-9.763 x_{h}-349.3 x_{i}
\end{aligned}
$$

$T_{m}: m$ 月 $t$ 時の推定気温 $(\times 100)$

$x_{a}$ : 傾斜, $x_{b}$ : 地形のラプラシアン,$x_{c}$ : 海岸線からの距 離, $x_{d}$ : 相模湾からの距離(対数), $x_{e}$ : 東京湾の西側か らの距離(対数), $x_{f}$ :東京湾の東側からの距離(対数), $x_{R}$ : 人工被覆率, $x_{h}$ :農地率, $x_{i}$ : 植生指標 


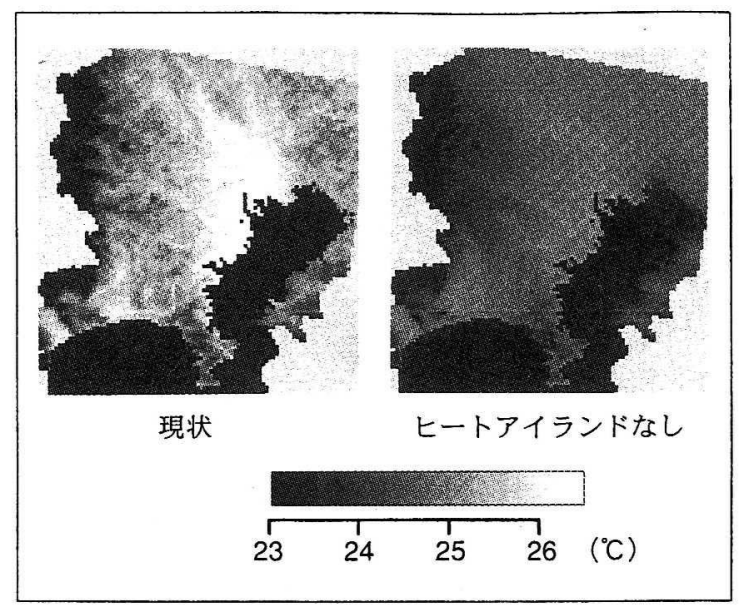

図-5 気温分布のメッシュ推定值 (8月20時の例)

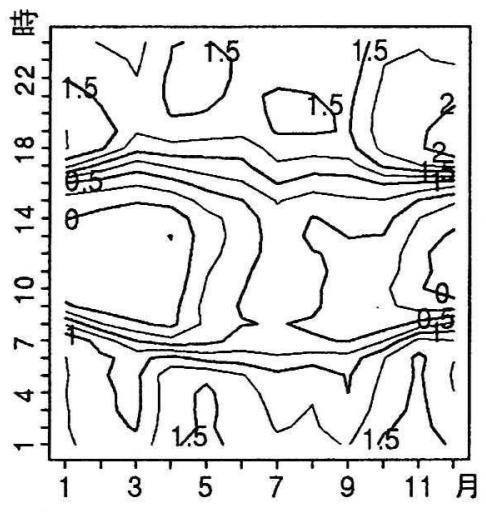

現状一都市の効果なし

図-6 気温差のアイソプレス $\left({ }^{\circ} \mathrm{C}\right.$

次に，都市の影響がない場合の仮想的な気温分布 を推定した.これは, 前述した説明変数のメッシュ データの土地利用率や植生指標に非都市域の值を代 入し,これに同様の重回帰式を適用するという方法 により行った。 ただし，説明変数の土地利用率や植 生指標の間には強い多重共線性がある（ $R=0.5 \sim 0.7$ 程度）。一方，土地利用率や植生指標と地形因子や 海岸距離の間にはほとんど多重共線性はない （ $R=0.0 \sim 0.3$ 程度）。したがって，ある程度信頼性 のある予測值を得るためには，土地利用率および植 生指標を整合性のある形で変化させる必要がある. また，重回帰式を当てはめることにより予測するた め, 極端な外挿は避ける必要がある。これらの理由 から, 対象地域内の非都市域の土地利用率や植生指 標を都市域に当てはめるという方法が適切であると 考えられる。このため,ここでは郊外の代表地域と して神奈川県秦野市を選択し, 植生指標が秦野市の

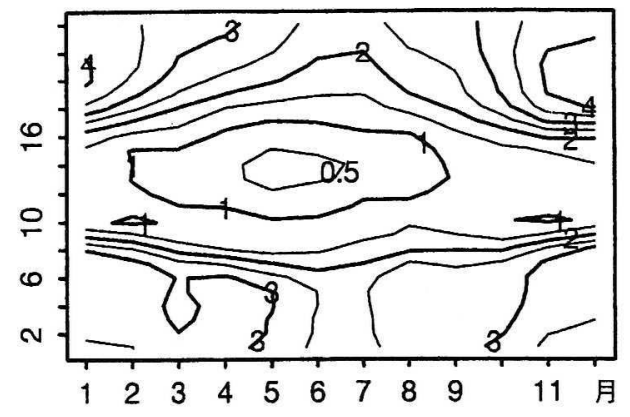

図-7 ヒートアイランド強度 ${ }^{14)}\left({ }^{\circ} \mathrm{C}\right)$

平均値未満のメッシュの土地利用率・植生指標をす べて秦野市の平均值に置き換えた。そ和上で，同様 の重回帰式を当てはめることにより，都市の影響が ない場合の仮想的な気温分布を推定した.

これらの推定により得られた気温分布の 8 月 20 時 の例を図-5に示す。また，大手町の月別・時刻別の 気温差（現状 - 都市の効果なし）を図-6にアイソ プレスとして示す．図-6から，都市の影響による昇 温が最大となるのは 12 月 19 時で, $2.2{ }^{\circ} \mathrm{C}$ 程度である ことがわかる.

\section{(2) 妥当性の検討}

前節において行った気温分布の推定結果は，精度 の定量的な検証が非常に困難である。このため，こ こでは他の手法による推定結果との定性的に比較に より妥当性を確認するだけにとどめた．定量的な検 証に関しては，重要な今後の課題であると言える. なお，第6章2節においては，気温分布の推定誤差が 最終的なエネルギー消費量の推定結果に与える影響 を概算することで，結果の信頼性の評価を試みてい る.

a) ヒートアイランド強度との比較

ヒートアイランド強度とは都心と郊外の気温差に より定義され，都市の影響による昇温を近似する指 標である。ただしこれは，空間分布を把握できない こと, 異なる 2 点の気温差なので都市以外の影響が 含まれていることなどが本研究の推定手法と異な る.

ここでは丸の内と青梅をそれぞれ都心と郊外の代 表点として算出したヒートアイランド強度のアイソ

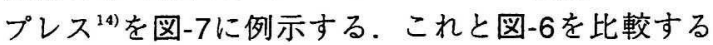
と，冬季の夕方過ぎにピークがあり，都市の影響に よる昇温が主に夜間に生じること，冬季に比較的顕 著であることなどの傾向はよく一致していると言え る.

また，夏季日中には図-7は図-6と比較して相対的 


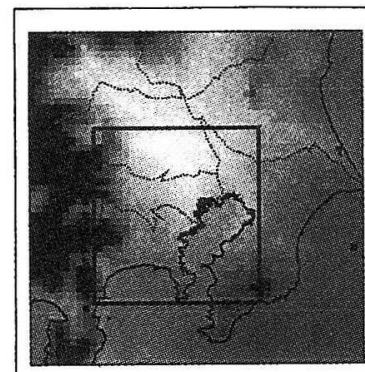

現状

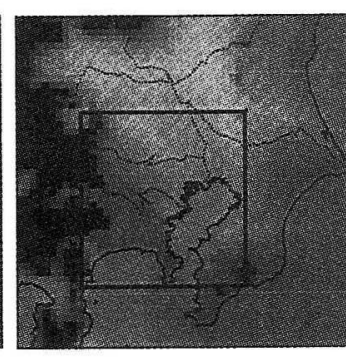

ヒートアイランドなし

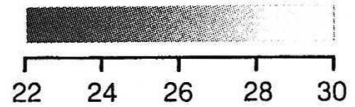

$\left({ }^{\circ} \mathrm{C}\right)$

図-8シミュレーション結果 ${ }^{(5)}$ (8月20時の例)

に低いが,これは都心部が東京湾からの海風の冷却 効果を受けるため, 結果としてヒートアイランド強 度が低くなったと考えられる。また, 絶対値は図-7 の方が大きいが，これは都心部が海洋の保温効果の 影響を受けることと，想定している土地利用条件の 違いの両方によると考えられる．したがって，相違 点に関しても整合性があり，妥当な結果であると考 えられる.

b) 数值シミュレーションとの比較

都市の影響がない場合の気温分布の推定は, 物理 モデルの数值シミュレーションにより行うことが一 般的である。しかしながら，これはある特定の気象 条件を再現する手法であるのに対し, 本研究の手法 は気候值（長期間の平均値）として平均気温の分布 を推定するものであり，性質が異なる，したがって 定量的な検証は困難なので,ここでは定性的な比較 にとどめ, 妥当性を確認した。

比較対象は, 計算条件や対象地域が本研究と類似 している例として気象庁によるシミュレーション結 果 ${ }^{15)}$ 用いた。これは東京を中心とした $200 \mathrm{~km} \times$ $200 \mathrm{~km}$ の範囲を対象とし, 現状および都市を取り除 いた場合の気温分布を $4 \mathrm{~km}$ メッシュでシミュレー ションしたものである. 都市を取り除いた場合と は, 人工排熱をなくし, 都市的土地利用をすべて 林, 水田, 畑とした状態を想定している。また太陽 高度は8月 15 日に設定し, 気象条件は典型的な晴天 日を想定している。

まず，空間分布について検討するため，このシ ミュレーション結果を図化し, 前述した重回帰式に よる月別・時刻別メッシュ推定値と比較した. ここ では図-5と対応させるため，20時の例を図-8に示 す. 図-8は現状の気温分布では都心部を中心とし埼 玉方面へ高温帯が広がっているが, 都市の影響をな
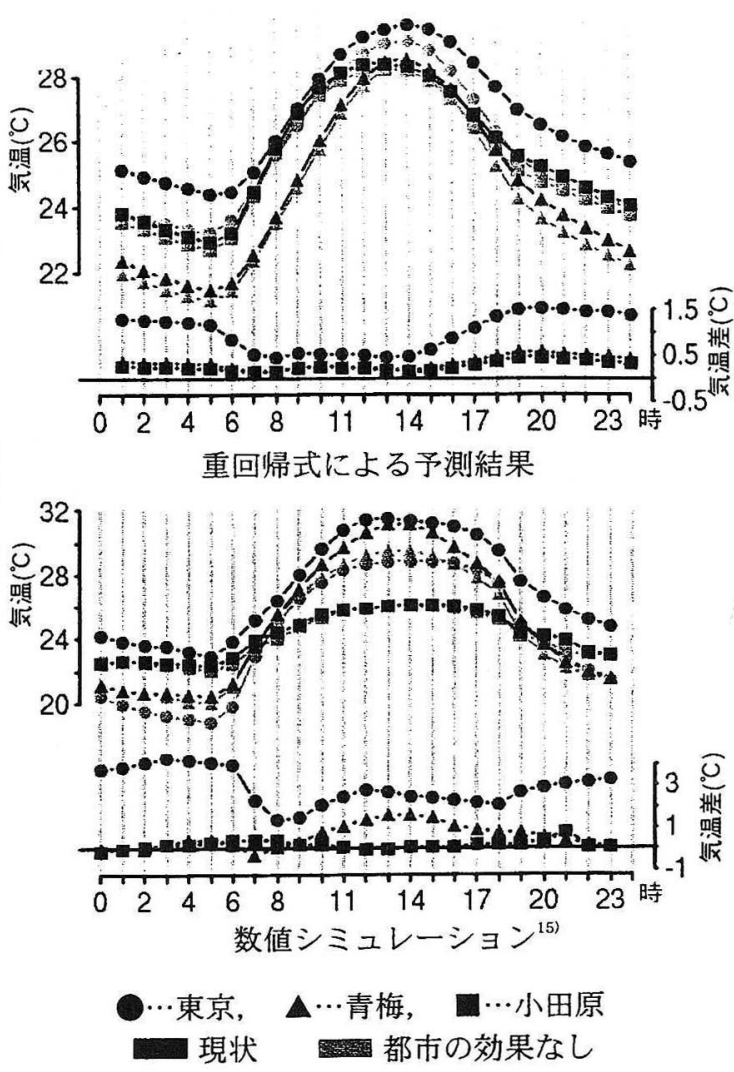

図-9 気温予測結果の比較 (8月の日变化パターン)

くした場合はこの高温带が見えないという点が特徵 的である。これらは対象とするスケールが異なるた め詳細な比較は困難であるが，定性的にはよく一致 していると言える。また，他の時刻についても同様 に比較し，よく一致していることが確認された。

次に, 大手町, 青梅, 小田原の3カ所について, 現状と都市の影響がない場合のそれぞれの気温およ びこれらの気温差の日変化パターンを比較した（図9）。この結果, 都市の影響による昇温は大手町が 最も顕著であり, 青梅, 小田原の順でこれに続くこ と, 日中と比較し夜間に顕著であることといった傾 向は比較的よく一致していると言える.

ただし，本研究における推定値は昙天日などを含 む平均値であるのに対し，シミュレーションは晴天 日を想定しているため違いが生じている。例えば, 都市の影響による昇温がピークに達するのは,メッ シュ推定值では夕方過ぎであるのに対し, シミュレ ーション結果では明け方近くである。ヒートアイラ ンドは, 晴天時は夜半過ざから明け方にかけて顕著 であるのに対し，䡒天時は夜半にかけて発達しその 後は弱まるといわれており ${ }^{16)}$, 整合性はある。また 
シミュレーション結果では, 小田原の日中の気温が 他と比較して低いが, これは相模湾からの海風の冷 却効果が晴天日の夏季・日中に強く生じるためであ る。その他, 都市の影響による昇温はシミュレー ション結果の方が大きいが,これは晴天時において ヒートアイランド現象が顕著に生じやすいこと ${ }^{16)}$, 想定した土地利用・土地被覆条件が異なることの両 方によると考えられる。

以上の検討から, 本研究の気温推定値の時空間的 な変動パターンは, ヒートアイランド強度とも数值 シミュレーションの結果ともよく一致しており，的 確であると言える。また相違点に関しても，想定し ている条件の違いを考慮すれば整合性があり，定性 的にはほぼ妥当な結果であると考えられる。

なお，昇温の変動幅の大きさは過小評価になって いる可能性があるが，これは想定する土地利用条件 により変わるものであるため問題はない. ただし， 本研究はあくまでここで示した気温分布を設定した 場合の影響評価と位置づける必要がある。

\section{5. 居住世帯数のメッシュデータ作成}

ここでは家庭部門のエネルギー消費原単位の基礎 指標である世帯数のメッシュデー夕を作成した。そ の手順を以下に示す.

まず図-10に兏色で示した地域に関しては，「住 宅統計調査報告」による市（区）町村の行政区ごと の世帯数および建物数のデータ ${ }^{17)}$ が利用可能であ る。そこでこれを用い，戸建住宅・共同住宅のそれ ぞれの行政区ごとの世帯数を算出した。また，細密 数值情報に含まれる行政区分のメッシュデータを用 いて, 戸建住宅と集合住宅の $1 \mathrm{~km}$ メシュ床面積デ

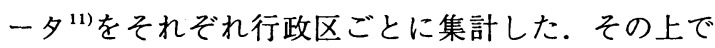
これらを用いて，世帯数を行政区ごとに床面積で重 みづけする形で $1 \mathrm{~km}$ メッシュに配分した。計算式 は,

$$
h_{n}=H \cdot f_{n} / \Sigma f_{n}
$$

$H:$ ある行政区の世帯数

$h_{n}$ : ある行政区の $n$ 番目のメッシュの推定世帯数

$f_{n}:$ ある行政区の $n$ 番目のメッシュの床面積

である。

また，図-10に黒で示した地域は「住宅統計調査 報告」からは世帯数を特定できない。これらは「住 宅統計調査報告」にデータが記載されていない行政 区（人口 2 万人以下の行政区）および，本研究の対 象地域に区域全体が含まれてない行政区である。な

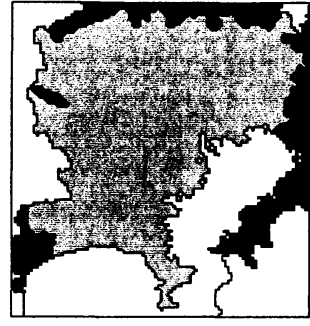

1. 世帯数の統計 データをメッ シュに分配

2. 回帰式により 推定

対象地域外

図-10 世帯数推定のための地域分類
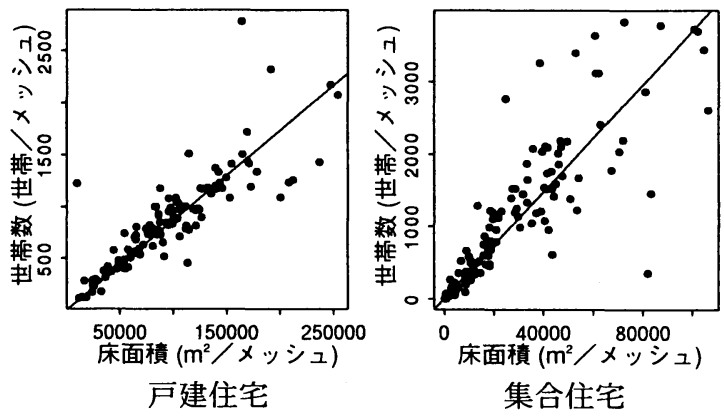

集合住宅

図-11 床面積と世帯数の関係（1メッシュあたり）

お後者をできる限り少なくするため, 図-1に「デー 夕なし」と記した地域のうち, 床面積データおよび 行政区分データが利用可能な地域は, ここでは対象 地域に組み込んだ。

これらの地域は回帰式を用いて世帯数を推定し た。まず図-10に灰色で示した地域の行政区ごとに 集計した床面積および世帯数の散布図を図-11に示 す。ただし，各行政区の面積の違いから生じる相関 の影響を除去するため, 世带数, 床面積とも1メッ シュあたりとした。また都心部はこの関係が直線的 ではなかったため, 東京23区は除外してある。この 図から，これらはほほ比例関係であることが読み取 れる。 そこで，原点を通る回帰式を作成した結果，

$$
\begin{aligned}
& y_{1}=0.00866 x_{1} \quad(R=0.856) \\
& y_{2}=0.0370 x_{2} \quad(R=0.847)
\end{aligned}
$$

$y_{1}:$ 戸建住宅の世帯数（1メッシュあたり）

$x_{1}$ : 戸建住宅の床面積（1メッシュあたり）

$y_{2}$ : 集合住宅の世帯数（1メッシュあたり）

$x_{2}$ : 集合住宅の床面積（1メッシュあたり）

を得た。この式を用い, 図-10に黒で示した地域に おいては床面積のメッシュデータから世帯数を推定 した。この地域はほとんどが郊外であるため, 居住 世帯数は少なく，ヒートアイランド現象による昇温 も小さい. したがって, 式(4)には多少のばらつきが 


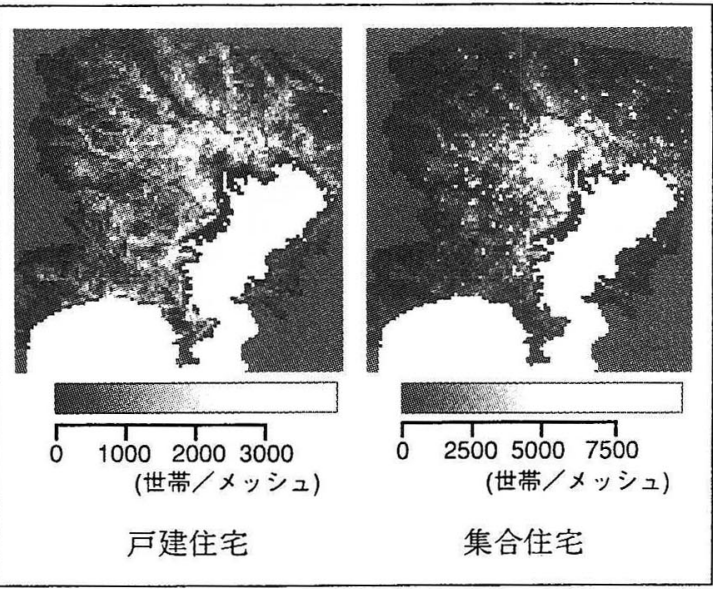

図-12 世帯数のメッシュデータ

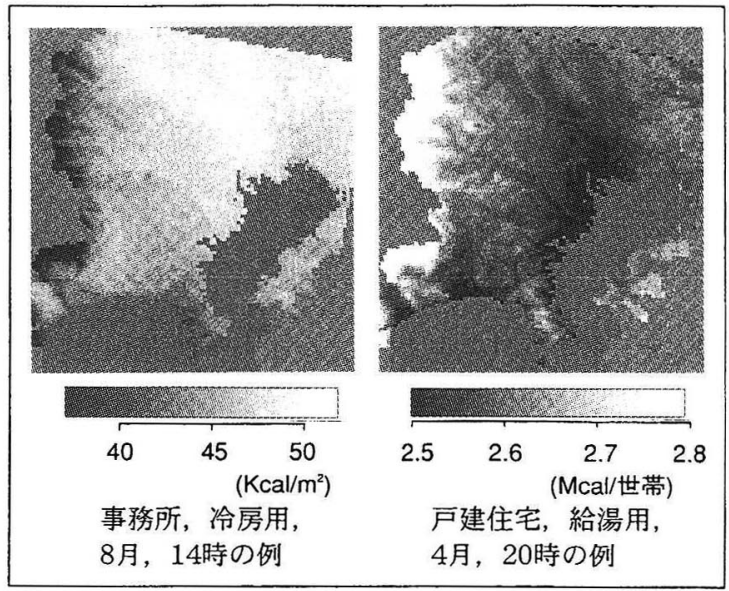

図-13 エネルギー消費原単位の空間分布

あるが，結果には大きな影響を与えないと考えられ る。

なお式(4)を世帯あたりの床面積に換算すると，集 合住宅は27 ( $\mathrm{m}^{2} /$ 世帯) となり,すこし少ないと思 われる。これは, 住宅以外の建物に居住する世帯を 集合住宅に居住する世帯の中に組み込んだことによ る差や, 床面積のデータと世帯数のデータの夕イム ラグなどにより生じていると考えられる。また，本 研究において用いた床面積のメッシュデータは「固 定資産税概要調書」に基づいて作成されているた め, 住宅の総床面積は信頼できるが, 戸建・集合の 配分には誤差が含まれている可能性がある、いずれ にせよ「住宅統計調査報告」はより信頼できると考 えられるため, 本章で作成した世帯数のメッシュデ 一夕は利用可能な精度であると考えられる.

以上の結果により得られた世帯数の分布図を図12に示す.

\section{6. 都市ヒートアイランド現象の影響評価}

\section{(1) エネルギー消費量の推定と比較}

まず，第 4 章において推定した気温分布のメッ シュデー夕に第3章で作成した推定式をメッシュ単 位で適用した。また，第3章において推定式を作成 した際の残差を足しあわせ，值を補正した，第3章 において作成した推定式は建物用途別・用途別・時 刻別のエネルギー消費原単位を気温から推定するた めのものであり, 気温のメッシュデー夕は, 月別 時刻別のメッシュデータである. したがって, 建物 用途別・用途別 · 月別 - 時刻別エネルギー消費原単

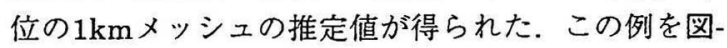
13に示す.

次に,このエネルギー消費原単位を基礎指標の

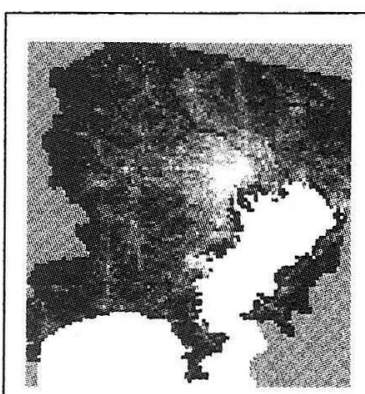

業務部門, 冷房用, 8 月, 14 時の例

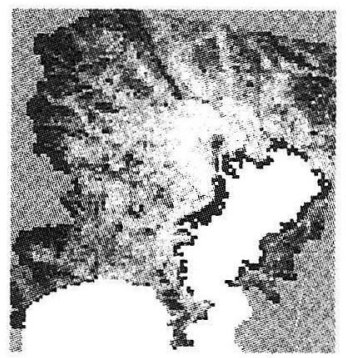

家庭部門, 給湯用, 4月, 20 時の例

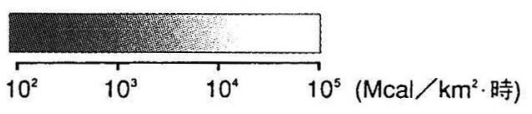

図-14 エネルギー消費の空間分布 メッシュデータにメッシュ単位で乗じることによ り，エネルギー消費量の空間分布を推定した．用い た基礎指標のデータは，家庭部門は第 5 章において 作成した世帯数のメッシュデー夕, 業務部門は床面 積のメッシュデータ ${ }^{11}$ である。そその上でこの建物用 途を家庭部門および業務部門に集約し，エネルギー 消費量の部門別 · 用途別 · 月別 - 時刻別のメッシュ 推定值とした.この例を図-14に示す.

また，第4章で推定した都市の影響がない場合の 仮想的な気温分布に関しても，同様の推定式と基礎 指標のデータを用い, 部門別·用途別·月別・時刻 別エネルギー消費量をメッシュ単位で推定した。こ れはヒートアイランド現象が生じないと仮定した場 合に予想される仮想的なエネルギー消費量であるた め,これらの比較により, ヒートアイランド現象の エネルギー消費への影響を定量化できる.

そこでまず，現状とヒートアイランドがない場合 


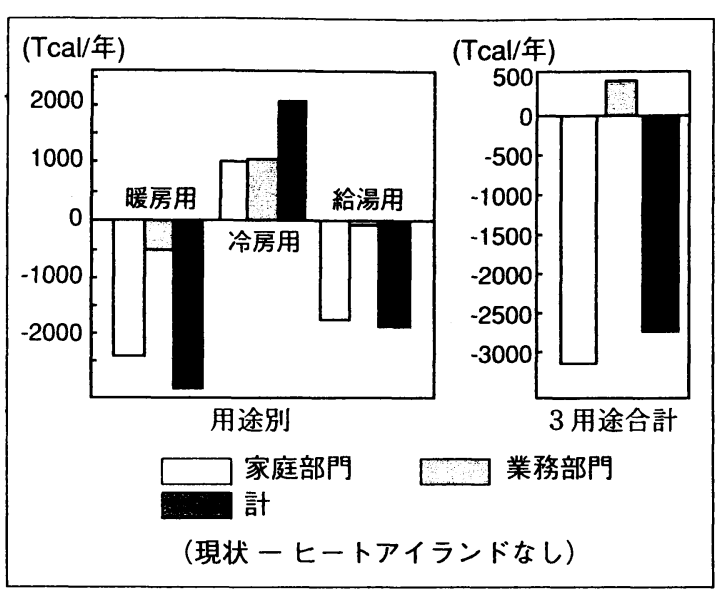

図-15 年間総消費量の差

のそれぞれについて，対象地域全体の部門別・用途 別の年間総消費量およびその差を算出した（図15).

この結果, 家庭部門においては，ヒートアイラン ド現象により暖房用エネルギー消費は約2400Tcal/ 年（10100TJ/年），給湯用エネルギー消費は約 $1800 \mathrm{Tcal} /$ 年 $(7300 \mathrm{TJ} /$ 年) ほど減少していることが 示された。これに対し，冷房用エネルギー消費の増 大は約 $1000 \mathrm{Tcal} /$ 年 $(4100 \mathrm{TJ} /$ 年) であり，変動幅は 暖房用・給湯用の減少分と比較すれば小さい。この ため, 結果として家庭部門全体ではエネルギー消費 量は約3200Tcal/年（13300TJ/年）ほど減少してい る.

一方, 業務部門ではヒートアイランド現象により エネルギー消費は増大している，とくに冷房用エネ ルギー消費の増大が大きく，このため3用途の合計 としては約400Tcal/年 $(1800 \mathrm{TJ} /$ 年) ほど増大して いる.

この業務部門のエネルギー消費の増大分は, 家庭 部門における減少分と比較すれば，明らかに小さ い.このため, 両部門の合計では, 現状の気温分布 の方が約 $2800 \mathrm{Tcal} /$ 年 (11500TJ/年) ほど少ない. したがって, 東京ではヒートアイランド現象により 空調・給湯用エネルギー消費は隇少しているという 結果となった. 変動率は, 空調・給湯用エネルギー 全体で家庭部門において $3.6 \%$ の減少，業務部門にお いて $1.3 \%$ の増大，両部門合計では $2.3 \%$ の減少であ る.

また，熱環境という観点からはこうした評価は季 節・時間帯別に行なう必要がある.そこで夏季・冬 季・中間季および日中・夜間に分け，それぞれ1カ 月あたりのエネルギー消費の増減を算出した（図16）.なお，ここでは 6 ～8月を夏季， 12２月を冬

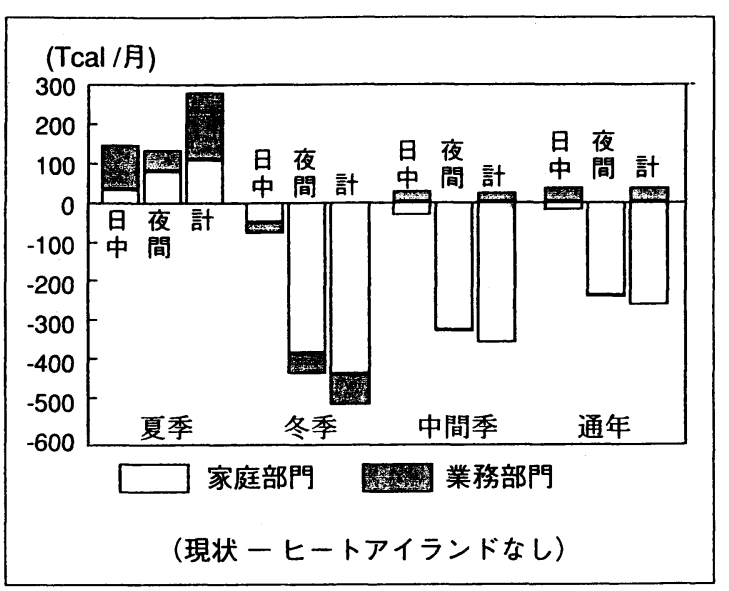

図-16 季節別・時間帯別消費量の差（1カ月あたり）

季，3〜5月および9〜11月を中間季とし，また6〜 17時を日中, 18〜5時を夜間とした.

この図から，夏季のエネルギー消費は家庭・業務 両部門とも同程度に増大していることがわかる。ま た冬季には両部門とも減少しており，とくに夜間の 家庭部門が強く影響を受けている。中間季の日中 は, 家庭部門では減少し, 業務部門では増大してい るが, どちらも変動幅は小さい。中間季の夜間は冬 季と同様に家庭部門が強く影響を受けており，業務 部門への影響はほとんどみられない。なお,これら のエネルギー消費構造のさらに詳細な検討は3節に おいて行うことにする.

\section{(2) 気温感応度に着目した感度解析}

今回算出したエネルギー消費量の推定值は, 推定 に利用されたさまざまな推定式や仮定の影響を受け る.したがって，これらの誤差が結果にどの程度の 影響を与えるかをできるだけ定量的に評価すること が重要である。とくに最終結果に大きな影響を与え 得る要素としては, エネルギー消費原単位の推定式 および気温分布の推定精度が考えられるが, 前者に 関しては第3章において信頼性を検討し，良好な結 果が得られている。したがって，これは気温分布の 精度に比べ重要性は低いと判断し，ここでは気温分 布の推定誤差に焦点をあてて感度解析を試みること とした．感度解析にあたっては，気温変化に対応す るエネルギー消費量の変化（気温感応度）を算出す ることにより，都市による昇温やその推定誤差が工 ネルギー消費量の推定結果に与える影響について検 討した。

エネルギー消費原単位の推定式は折れ線または直 線で近似したため, 都市による昇温とエネルギー消 費の増減は, 昇温幅が小さければほほ比例関係とし 


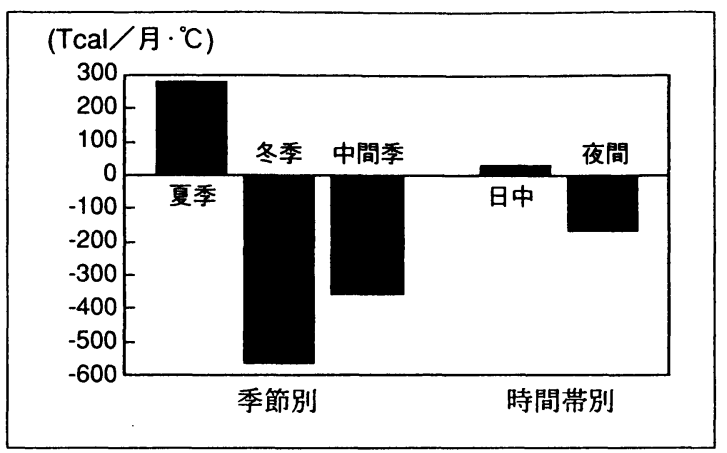

図-17 気温感応度（1カ月あたり）

て近似できる。そこで，前節で定義した夏季・冬 季・中間季および日中・夜間に分け，それぞれにつ いて昇温の変動パターンおよび対象地域のエネルギ 一消費の増減から気温感応度を概算した（図一 17）。ただし，昇温パターンは場所により異なるた め,ここでは代表地点として大手町における昇温パ ターン（図-6）を用い，他の地点は大手町の昇温幅 に比例する形で設定した。したがって図-17は，第4 章で推定した昇温の空間分布を保持したまま大手町 の昇温幅が $1{ }^{\circ} \mathrm{C}$ 拡大した場合, 1 月あたりのエネル ギー消費量がどの程度の増減するかを示すものであ る.

この図から，夏季は冬季・中間季と比較して昇温 幅によるエネルギー消費量の変動が小さいことがわ かる.これは主に冷房用エネルギーの増大と給湯用 エネルギーの減少が互いに打ち消し合うためであ る。この結果を用い，夏季において冬季・中間季の 4倍以上の昇温が生じない限り，夏季のエネルギー 消費の増大分が冬季・中間季の減少分を上回らない ことが算出できる。

また，日中と夜間を比較した場合，日中はわずか に正の気温感応があるが，実際には夏季のエネルギ 一消費の増大と冬季のエネルギー消費の減少により ほとんど相殺されている。これに対し，夜間は家庭 部門の暖房・給湯用エネルギーなどが大きく影響す るため, 負の気温感応が生じている。この結果か ら，日中において夜間の6倍近い昇温が生じない限 り，日中のエネルギー消費の増大分は夜間の減少分 を上回らないことが算出できる。

本来は季節と時間帯の両方の誤差を同時に評価す べきであるが，繁雑になるのでこれ以上の検討は省 略する。しかしながら，よく言われるとおりヒート アイランド現象が冬季に生じやすく夜間に顕著であ るとすれば, ヒートアイランド現象により東京にお ける通年のエネルギー消費が減少していることは， ほほ間違いないと考えられる。
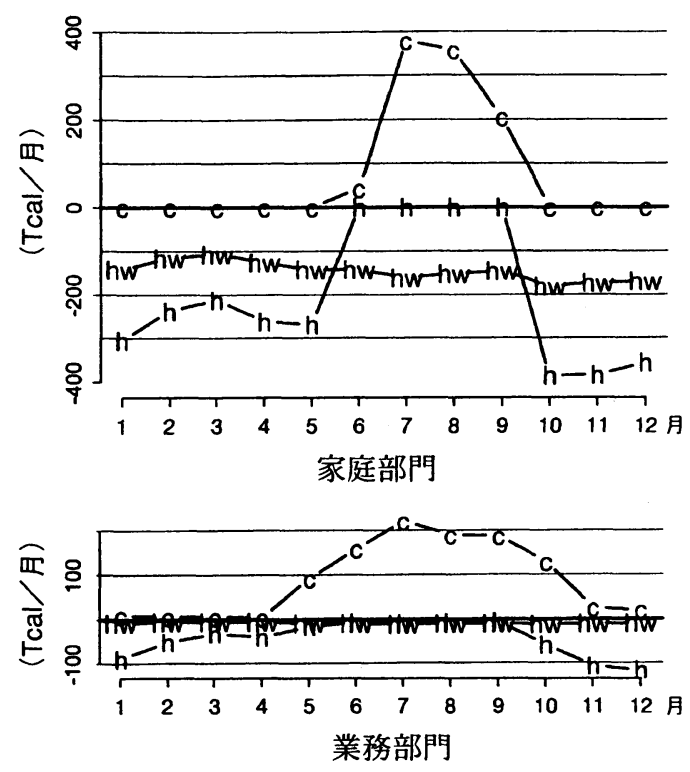

h. 暖房用, c. 冷房用, hw. 給湯用

（現状一ヒートアイランドなし）

図-18 用途別・月別消費量の差

\section{(3) 時空間変動パターンの構造解析}

次に,ヒートアイランド現象によるエネルギー消 費の増減の構造を明らかにするため, まず増大量 （現状一ヒートアイランドなし）を用途別・月別に 計算した（図-18）。この図から，暖房用エネルギ 一消費の減少は，家庭部門では大きく，また10月か ら5月までの長期間にわたって生じているのに対 し，業務部門では比較的小さいことがわかる。 た，冷房用エネルギー消費の増大は家庭・業務の両 部門において生じている。この影響は，家庭部門に おいては7月から9月までの短期間であるが変動幅は 大きく，業務部門においては5月から10月までの長 期間にわたって生じているが，変動幅は家庭部門と 比較して小さいと言える。給湯用エネルギー消費 は，家庭部門においては年間を通じて減少している が，業務部門においてはほとんど影響は見られな い. 家庭部門の給湯用エネルギーは風呂が大きな割 合を占めており，これが気温の影響を受けやすいた めにこうした違いが生じていると考えられる。

次に1月の暖房用，8月の冷房用，4月の給湯用の それぞれについて，現状とヒートアイランドがない 場合の時刻別エネルギー消費量およびその差（現状 ーヒートアイランドなし）を計算した（図-19）。

図-19の下段に示した現状とヒートアイランドな しの差の図から，エネルギー消費がヒートアイラン ド現象の影響を強く受けるのは家庭部門の18２2時 

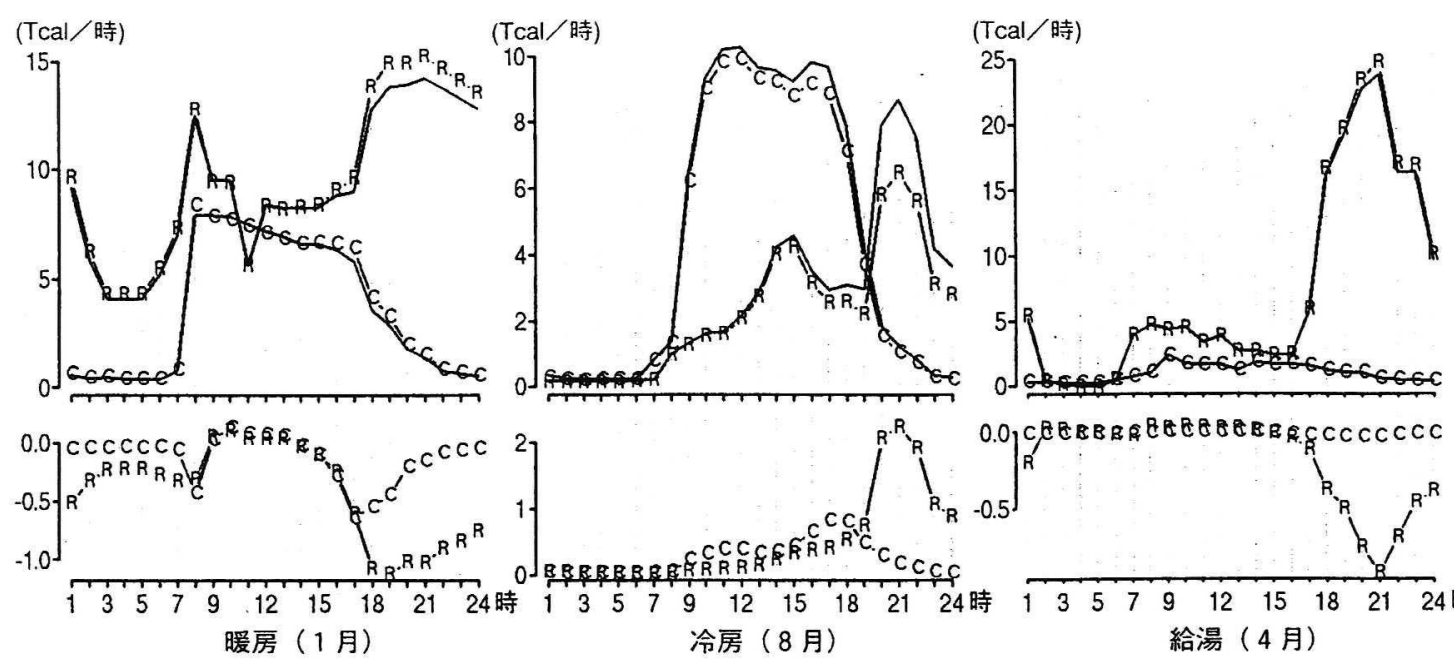

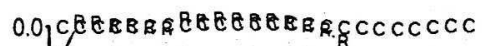

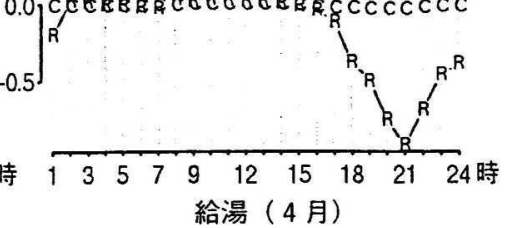

R. 家庭部門，C. 業務部門

上段：時刻別エネルギー消費量（記号 $\cdots$ ヒートアイランドなし，実線 $\cdots$ 現状）

下段：エネルギー消費量の差（現状一ヒートアイランドなし）

図-19 時刻別消費量および消費量の差（1月の暖房， 8 月の冷房，4 月の給湯の例）

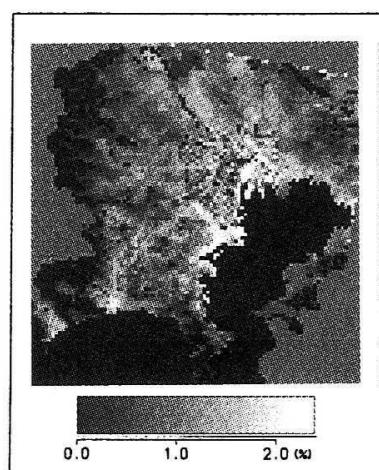

業務部門

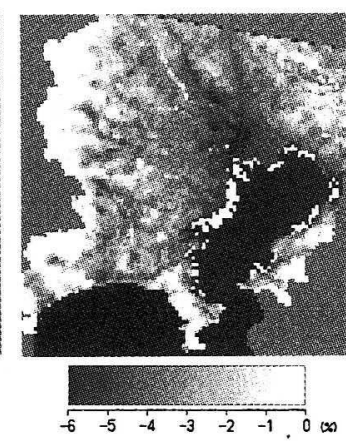

家庭部門 $\frac{\text { 現状一ヒートアイランドなし }}{\text { ヒートアイランドなし }} \times 100$

$(\%)$

図-20 年間消費量の増大率の空間分布

頃であることが読みとれる．図-6から読み取れる通 り，都市の影響による昇温が18時頃から6時頃まで の間が顕著であるのに対し, 家庭部門のエネルギー 消費量は18～22時頃に多い.この両方の影響によ り，ヒートアイランド現象は夕方の家庭用エネルギ 一消費に大きく影響するという解釈が可能である.

さらに,ヒートアイランド現象による影響の空間 分布を把握するため, メッシュ別に増大率・減少率 を算出した（図-20）。この図から，家庭部門にお いては住宅が存在しない東京湾の埋立地を除けば, 都心部を中心にエネルギー消費が減少していること
が読み取れる.一方，業務部門に関しては分布形は 複雑であるが, 概ね湾岸沿いに千葉から横浜付近ま で増大率が大きい地域が広がっていると言える.

\section{7. まとめ}

本研究では東京大都市圈を対象とし, 都市ヒート アイランド現象が民生部門の空調・給湯用エネルギ 一消費に与えている影響の定量化を目的とした。こ のため，まずエネルギー消費原単位の気温による推 定式を作成し，その一方で現状の気温分布およびヒ 一トアイランドが生じないと想定した場合の気温分 布を推定した. その上で, それぞれの気温分布につ いて，エネルギー消費の空間分布をメッシュ単位で 推定し, 結果を比較した。 その結果ヒートアイラン ド現象により, 総エネルギー消費量は減少している こと, 家庭部門では暖房・給湯用エネルギー消費の 減少，業務部門では冷房用エネルギー消費の増大が 大きいこと，夕方から夜にかけて家庭部門において 影響が大きいことなどが明らかになった，概算值と しては, 都心部において最大 $2.2^{\circ} \mathrm{C}$ 程度の気温上昇が 生じていると仮定した場合, 空調・給湯用エネルギ 一の総和は家庭部門において $3.6 \%$ 減少, 業務部門に おいて $1.3 \%$ 増大し，両部門をあわせると $2.3 \%$ 減少 しているという結果を得た. したがって，ヒートア イランド緩和策の提案は数多いが, エネルギー消費 の增大を招く可能性があるため, その点では慎重な 検討が必要であると言える. 
また，今回の分析結果においては，全エネルギー 消費が減少するということ以外に，業務部門におい てはヒートアイランド現象により通年エネルギー消 費が増大していること, 夏季は業務・家庭の両部門 ともエネルギー消費が増大していることなどが重要 である。このため, 海陸風の利用や落葉樹による緑 化など，夏季に強い冷却効果が得られる対策がとく に有効であると考えられる，また，業務地区が集中 する都心部においては，ヒートアイランド緩和策に よりエネルギー消費を削減できる可能性が高い。そ こで本研究の今後の展望として,こうしたヒートア イランド緩和策のエネルギー消費への影響評価を行 なうことがあげられる。これにより現実的な政策・ 計画に応用可能な成果を導くことができると考えら れる.

また，ヒートアイランド現象によるエネルギー消 費の増減は，実際にはその都市の気候・風土や都市 活動のあり方などにより異なる，例えば，本研究で 対象とした東京大都市圈においてはエネルギー消費 が減少することが示されたが，より温暖な地域では 増大する可能性が高い. とくに，急速な都市化が進 行している発展途上国の多くが熱帯に位置すること を考慮すれば，決して楽観できる状況ではない。し たがって今後，様々な都市においてこうした検討を 行う必要があると考えられる。また東京において も, 冷房需要が年々増大していることを考慮すれ ば，将来的には傾向が変わり得るものである．した がって今後こうした評価は継続的に行う必要がある と言える。こうしたことから, 本研究で提案した手 法は一般性があると考えているが, 得られた知見に 関しては, 今後さらに体系的で一貫した調査が必要 であることを付け加えておく.

謝辞: 本研究を進めるにあたり, 慶應義塾大学の清 水浩先生, 都市防災研究所アジア防災センターの鈴 木広隆先生, 東京大学の花木啓祐先生, 埼玉大学の 藤野毅先生にご助言をいただいた。また，東北工業 大学の渡辺浩文先生には床面積のメッシュデータ を, 気象庁気候情報課の高橋俊二先生には数值シ ミュレーションの結果をそれぞれご提供いただい た.ここに記して謝意を表します。

本稿は平野が1998年3月に慶應義塾大学に提出し た修士論文を加筆・修正したものである。また, 本 稿の一部は1998年度土木学会環境システム研究論文 発表会（アブストラクト審査部門）および, 1998年 度写真測量学会年次学術講演会において発表した。

本研究において使用した大気污染常時監視測定局 のデータは国立環境研究所環境データベースによる
大気環境時間值データファイルである.

\section{参考文献}

1) 山下偹二: 京浜地域の気候環境の变化, 小川一朗 編著: 『東京大都市圈の地域変容』大明堂, pp.115 126, 1989年.

2) 尾島俊雄: 都市污染, 空気調和 - 衛生工学, Vol.64, No.9, pp.729 733, 1990年.

3) 木村富士男: 都市の熱污染, 大気污染学会誌, Vol.27, No.6, pp.A87 94,1992年.

4) Meier, A. and Taha, H.: Mitigation of Urban Heat Islands: Meteorology, Energy, and Air Quality Impacts, Proceedings of "International Symposium on Monitoring and Management of Urban Heat Island", pp.124-163, 1997.

5)一ノ瀬俊明: シュトゥットガルトにおける「風の道」 一都市計画で都市気候を制御する試み一，天気， Vol.40, No.9, pp.691 693, 1993年.

6) 玄地裕, 霞 浩樹, 猿田弘行, 顧蔚新, 小宮山宏: 地 下ヒートシンク冷房を利用した新しいヒートアイラン ド対策の提案とその可能性の検討, エネルギー・資源, Vol.18, No.5, pp.491 497, 1997年.

7) 水野 稔: 24 時間都市の環境をめぐる諸問題一都市の七 ートアイランドを中心に一, 日本音響学会誌, Vol.49, No.11, pp.832 838, 1993年.

8）桘屋治紀: 都市とエネルギー循環, 環境情報科学, 19-2, pp. $23 \sim 27,1990$ 年.

9) 石野友夫: 家庭用暖房需要と気温の関係 一灯油と電力 の競合を考える〜, エネルギー・資源学会 第9回 エネ ルギーシステム・経済コンファレンス講演論文集, pp. $125 \sim 130,1993$ 年.

10) 須貝康雄, 堀部 浩, 川瀬太郎: 基準需要を利用した ニューラルネットによる翌日最大電力需要予測, 電気 学会論文誌B, Vol.117, No.6, pp.872 879, 1997年.

11) 渡辺浩文: 東京首都圈における熱污染のメッシュ別定 量化に関する調查研究, 早稲田大学博士論文, 1994年.

12) 一八瀬俊明, 花木啓祐, 松尾友矩: 細密地理情報にも とづく都市人工排熱の時空間分布の構造解析. 環境工 学研究論文集, Vol.31, pp.263 273,1994年.

13）守田 優: 都市人工熱源の熱環境負荷原単位について, 土木学会環境システム研究, Vol.24, pp.593 600, 1996年.

14) 平野勇二郎, 茅陽一: 関東平野南部における都市気温 分布の時空間構造解析, GIS-理論と応用, Vol.6, No.2, pp.1 10, 1998年.

15) 気象庁: 9-4 都市化と気候变動, 『異常気象レポート '94』, pp.303 313, 1994年.

16) 山添謙, 一>瀬俊明: 東京およびその周辺地域におけ る秋季夜間の晴天時と量天時のヒートアイランド, 地 理学評論, Vol.67(A), No.8, pp.551 560, 1994年.

17) 総務庁統計局: 『平成 5 年 住宅統計調査報告 第 3 巻 都道 府県編」，1995年. 


\title{
IMPACT ASSESSMENT OF HEAT ISLAND PHENOMENON ON ENERGY CONSUMPTION FOR AIR CONDITIONING, HEATING AND HOT WATER
}

\author{
Yujiro HIRANO, Yoichi KAYA and Ryosuke SHIBASAKI
}

The purpose of this research is to quantify the impacts of the heat island phenomenon on energy consumption for air conditioning, heating and hot water supply in the Tokyo metropolitan area. There are many indications showing that energy consumption for air conditioners may increase because of the heat island phenomenon. However, they ignore that energy consumption for heating and hot water supplies may decrease in winter. It is crucially important to take both aspects into account in order to quantify impacts. The results reveal that residential energy consumption decreases, while the commercial energy consumption increases. In addition, the total energy consumption decreases in the Tokyo metropolitan area under present air temperature rise due to the heat island phenomenon. 